\title{
PREDICTION OF THE VISTULA CHANNEL DEVELOPMENT BETWEEN WLOCLAWEK AND TORUN: EVALUATION WITH REGARD TO THE NEW GEOLOGICAL SURVEY
}

\author{
Zygmunt Babiński ${ }^{1}$, Michą Habel ${ }^{1}$, Sergey Chalov $^{2}$ \\ ${ }^{1}$ Department of Waterways, Kazimierz Wielki University in Bydgoszcz, Poland \\ ${ }^{2}$ Faculty of Geography, Moscow State University, Moscow, Russia
}

Manuscript received: May 31, 2014

Revised version: July 29, 2014

\begin{abstract}
BabińsKi Z., Habel M., Chalov S. Prediction of the Vistula channel development between Wloclawek and Torun: evaluation with regard to the new geological survey. Quaestiones Geographicae 33(3), Bogucki Wydawnictwo Naukowe, Poznań, pp. 7-15, 5 figs. DOI 10.2478/quageo-2014-0025, ISSN 0137-477X.

ABSTRACT: The aim of this paper is to present the geological structure of the Vistula river valley floor as the modifying factor of fluvial processes and present the development conditions of the contemporary Vistula river channel, which underwent marked transformation due to bed erosion and lateral erosion below the Włocławek reservoir. The analysis of the geological data and the geological survey conducted at the study reach of the Vistula between Włocławek and Torun resulted in an image of the geological structure of the channel bed along the longitudinal profile.
\end{abstract}

KEY WORDS: geological survey, geological structure, fluvial processes, Vistula River

Address of the corresponding author: Michat Habel, Institute of Geography, Department of Waterways, Kazimierz Wielki University in Bydgoszcz, Mińska 15, 85-428 Bydgoszcz, Poland; e-mail: hydro.habel@ukw.edu.pl

\section{Introduction}

Channels of alluvial rivers function in the state of a dynamic balance and consistently adjust their shape to average flows, transported material (Migon 2006, Alekseevsky and Chalov 2009) and prevailing climatic conditions (Beylich et al. 2011). Twindale (2004) pointed out the relation of the river valley resistant basement on the course of presentDay channel processes. According to Falkowski and Kowalski (1987), geological surveys of river valleys and their alluvia are of particular importance when planning construction of various kinds of structures - especially hydrotechnical. Features of channel morphology that are indices of a particular river regime and indicate the specific dynamics of erosional and accumulation processes, are increasingly dependent on the geological setting of the channel zone, particularly in reaches where the flood-water channel width is restricted by flood embankments (Falkowski 2010) and the average-water channel width is restricted by regulatory structures (e.g. river groynes). Damming a river and the consequent formation of a reservoir is an explicit example of the most dynamic transformation of a channel (Babiński 2002).

The aim of research was identification of the geological structure of the river valley floor as the modifying factor of fluvial processes. Understanding the development conditions of the contemporary Vistula river channel, which underwent marked transformation due to bed erosion and lateral erosion below the Włocławek reser- 
voir. Pursuing such objectives required completing the following tasks:

- specifying the range of bed erosion as defined by the thickness of alluvia transformed by the river into loamyClayey deposits that are resilient to the process.

- indicating the influence of river load deficit below the reservoir, artificially regulated conditions of water run-off and the occurrence of structures regulating the mean water channel on the directions of channel development.

The research may be of great significance for future prognoses regarding further operation of the Włocławek dam and the hydrotechnical development of the Vistula.

\section{Materials and methods}

The research covered the Vistula valley floor fragment (its channel in particular) stretching from the dam profile in Włocławek (river $\mathrm{km}$ $674+850$ ) to the gauging station profile in Torun (river km 734+700) (Fig. 1). According to the geographical division, the Vistula valley segment from Płock to Bydgoszcz-Fordon is referred to as Kuyavia Vistula (Falkowski, 1982). Pożaryski (1965) indicates that the river flows along the hidden anticline of Kujawy towards the coastal zone syncline. The river course is mainly parallel to the tectonic line which divides the Eastern European plate from the Western European fold system. The geomorphological research conducted by Galon (1934) on the other hand, indicated that the Lower Vistula developed into a system of eleven terraces, the youngest one being the

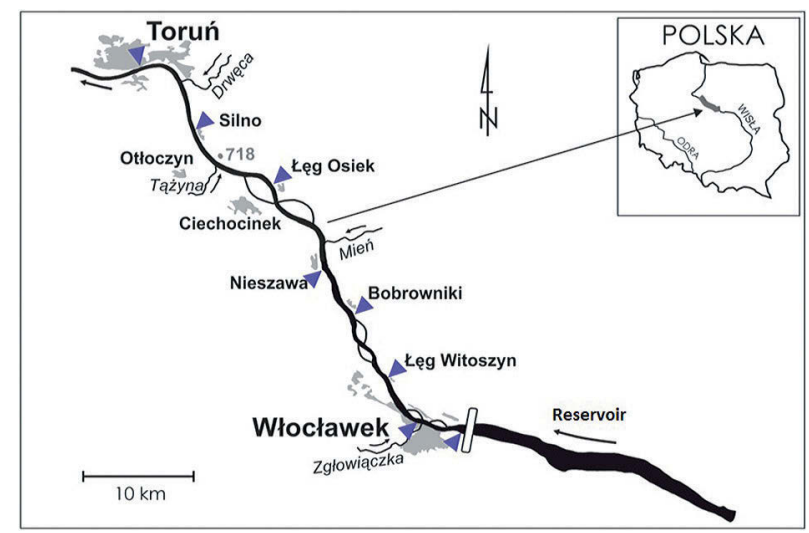

Fig. 1. The area of research showing the location of geological surveys in the work flood plain along with the channel. According to Wiśniewski $(1976,1987)$, this section of the valley floor is located within the gap zone of the Vistula between the Płock and Torun basins. It should be noted that the analysis covers the flood plain along with the channel. These forms are subject to contemporary fluvial processes and as such were extensively explored by the authors of this paper.

Thanks to the hydromorphological data and the archive data regarding the geological structure of the river floor, the authors were able to plan the location and scope of surveys to provide more detailed results in comparison to those available to date. The thickness analysis of transformed river sediments was based on the results of 40 depth surveys conducted within the navigation route in the years 1976-1995 and 2007-2012, as well as own measurements.

The geological structure of the valley floor was touched upon in numerous works (i.a. Galon 1934, Fąferek 1960, Wiśniewski 1976, 1987, Falkowski 1982, 1987, Tomczak, 1982, 1987, Babiński 1992, Babiński, Habel 2007). However, in order to provide possibly accurate results, the data was supplemented with the existing archive geological drillings and compared against the Detailed Geological Map of Poland (SMGP) in the scale of 1:50,000 for sheets: Włocławek, Bobrowniki, Ciechocinek and Torun. Furthermore, the authors performed geological works involving 18 drillings within the Vistula channel in 8 cross-sectional profiles on river $\mathrm{km}: 683+100$, $690+800,696+050,701+550,709+300,710+400$, 711+900, 719+500 (Fig. 3). Sediment samples representing consecutive geological strata were collected from each drilling. The material was subjected to sedimentological analyses at the Hydrochemistry and Sedimentology Laboratory of the Institute of Geography at Kazimierz Wielki University and is still being analysed.

The obtained results allowed for new interpretation of the geological structure along the longitudinal profile of the study section with regard to the extreme (maximum and minimum) elevation of the upper-most erosion-resilient deposits of Pliocene clay, including the thickness of the alluvia (clastic load) transformed by the Holocene Vistula (Fig. 3). Note that the profiles - Figures $3 \mathrm{~A}$ and $3 \mathrm{~B}$ do not indicate their course against 

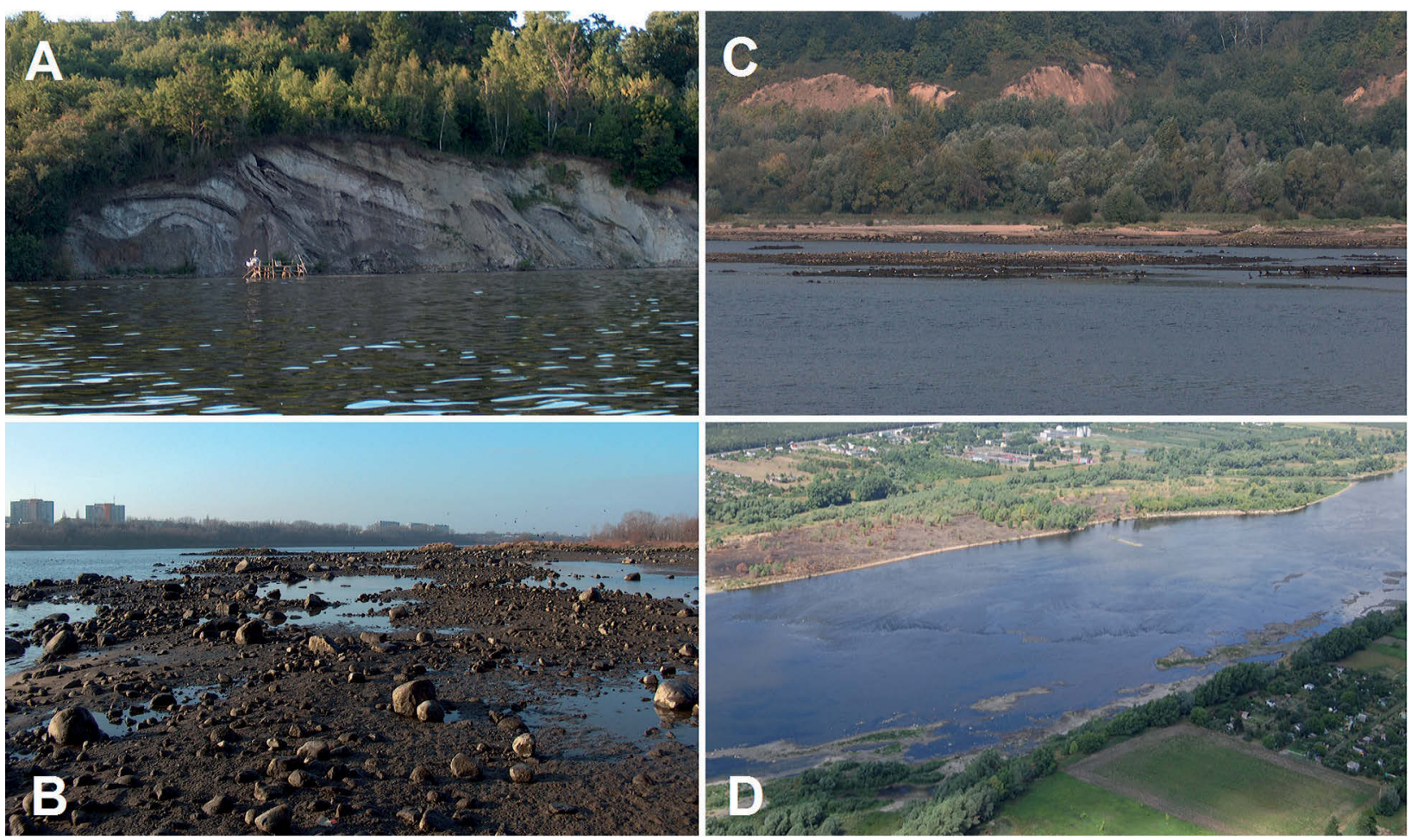

Fig. 2. Geological structures of selected sections of the Vistula between Wloclawek and Torun: A - deformed the Miocene formations (sands and lignite) in the vicinity of Dobrzyń on the Vistula River (Wloclawek Reservoir); B - stones and boulders lying on Pliocene clays in the area Grodzka Island (Kępa Grodzka) in Wloclawek $(681+100$ km); C - Dobrzyń Moraine

Plateau edge and emergent clay and stones in the vicinity of the dam in Wloclawek $(675+300 \mathrm{~km})$; D - the sill across the river channel in the vicinity Łęg Witoszyn $(683+00 \mathrm{~km})$

a specific river bank (left, right) or the thalweg, but against the extreme elevation of erosion-resilient deposits in a given cross-section (i.e. may be alternating). The geological structure along the longitudinal profile of the channel was presented against the background of fluctuating, due to bed erosion below the dam, water surface level.

\section{Research results}

The analysis of the archive geological data and the geological survey conducted at the study reach of the Vistula between Włocławek and Torun resulted in an image of the geological structure of the channel bed along the longitudinal profile (Fig. 3). Figure 3A shows that the contact of the Holocene alluvial formations corresponding to the maximum incision of the Vistula channel bed is limited to Cenosoic formations of Tertiary Miocene and Quaternary Pleistocene (glacial and interglacial-interstadial formations). The oldest, Miocene formations, constitute sand layers of various thickness and interbeddings of brown coal, with possible laminae of loam and silt. The structure and texture of these formations is evident from the uncovered fragments of the right-edge slope of the Włocławek reservoir (Fig. 2A), as demonstrated by M. Banach (1986). Thus, it can be assumed that the Miocene formations are significantly susceptible to river erosion.

Sedimentation of the Tertiary deposits, both the Miocene formations and Pliocene clay. appears to correspond to their horizontal pattern. However, as indicated by M. Banach (1986), the elevation of Pliocene clay and the lower located Miocene formations was deformed during the transgression of the Scandinavian ice sheet, thus leading to the height differences in their horizontal pattern (denivelation). This process can be observed in the uncovered right-edge slope of the Włocławek reservoir, as well as in the cross-section of the Vistula valley floor (Fig. 2C) presented by B. Fąferek (1960) on Figure 4. These two examples, which demonstrate denivelation of the sub-Quaternary surface, and which partially arise from the geological conditions presented in figures $3 \mathrm{~A}$ and $3 \mathrm{~B}$, indicate the possibility of a 

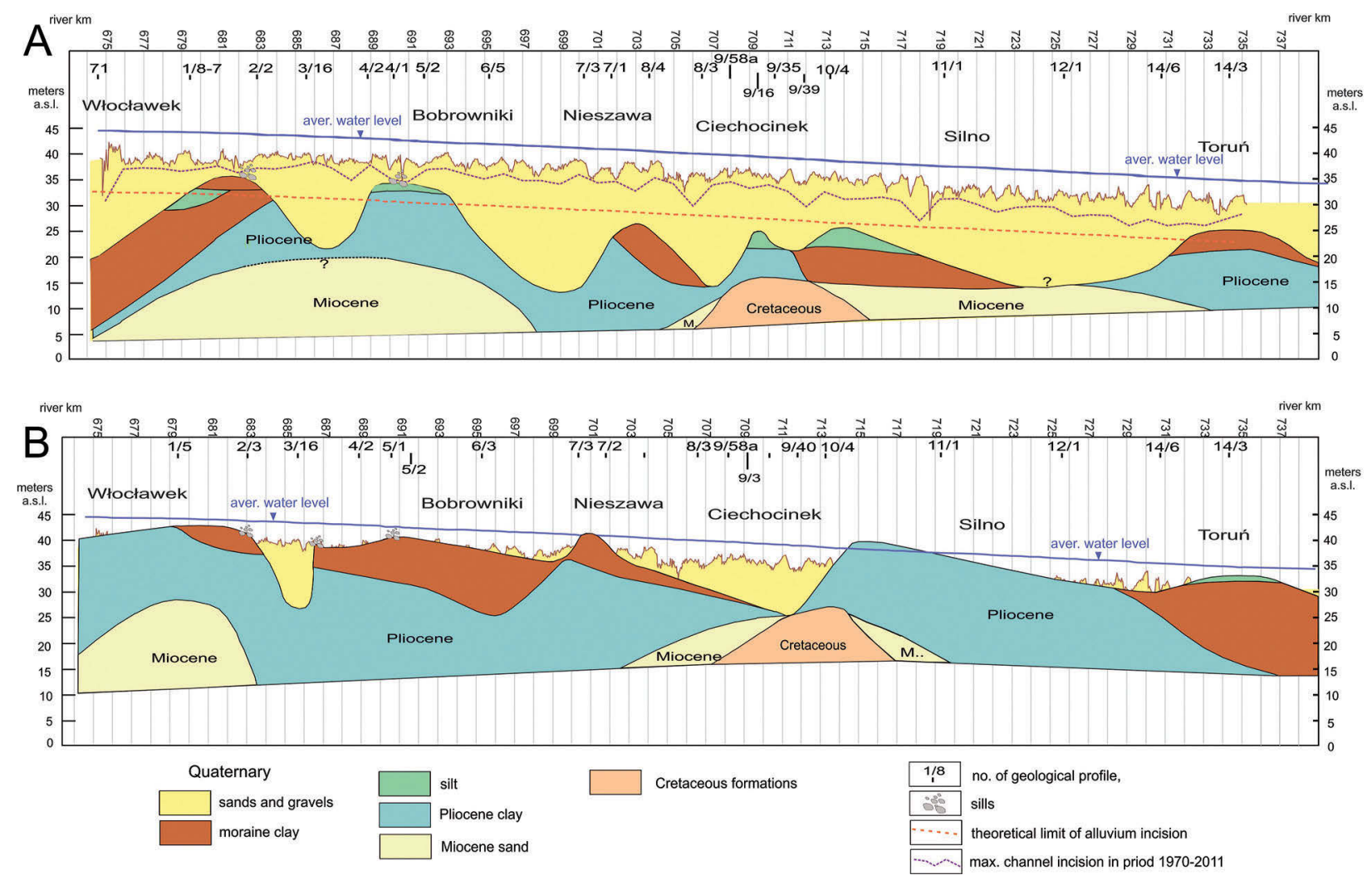

Fig. 3. Geological longitudinal profiles of the Vistula bed; the course of the maximum (A) and minimum (B) incision of the river channel during the Holocene period

"contact" between the contemporary channel bed and the erosion-susceptible Miocene deposits. The way the geological profiles at the Włocławek dam "overlap" with the maximum bed incision caused by bed erosion below the weirs of the face dam (Fig. 4) show that such a situation may occur, albeit it was not confirmed with field works. A situation where the river alluvia can directly contact the Miocene deposits occur at the Vistula reach stretching from river kilometre $686+00$ to $687+00$, and from $723+00$ to $727+00$ (Fig. 3A). Generally it can be assumed that, aside from the reach of intensive bed erosion in the direct vicinity of the face dam in Włocławek, there is a "protective mantle" that stretches down to Torun, and which prevents fluvial processes from reaching the erosion-susceptible Miocene deposits. However, it should be noted that such situation takes place only within the contemporary river valley zone. In other words, the analysis excludes, for instance, the Ciechocinek Lowland, where the Quaternary formations are deposited directly on top of the Mesozoic formations. The thickness of Pliocene clay ranges from approximately 1 m (Fig. 3A) to over $30 \mathrm{~m}$ (Fig. 3B). Nevertheless, these deposits can be locally missing at the reach from Ciechocinek (Fig. 3B) down to Torun (Fig. 3A).

Geological formations that tend to limit bed erosion in rivers are glacial sediments - moraine clay. At the Vistula valley floor section under study, moraine clay occurs in the form of islets resting on top of the Pliocene clay deposits significantly denivelated by the influence of the ice sheet and erosion processes of the ancient Vistula (pra-Wisła) (Fig. 3A and 3B). The analysis of the geological structure outside the Vistula channel showed that the moraine clay layers feature a stratigraphic continuity regardless of their age and origins. Only later, during the Holocene period did the Vistula cause the disruption of their continuity at its maximum incision into the bed. As moraine clay is subjected to washing out, it forms moraine till, which constitutes another factor that limits bed erosion. The moraine tills at the study reach may occur in the form of sills that partially or entirely dam the channel (Fig. 2D) - schematically indicated in figures 3A and 3B. They may also take on the form of a channel bed pavement, which can be found, among others, 


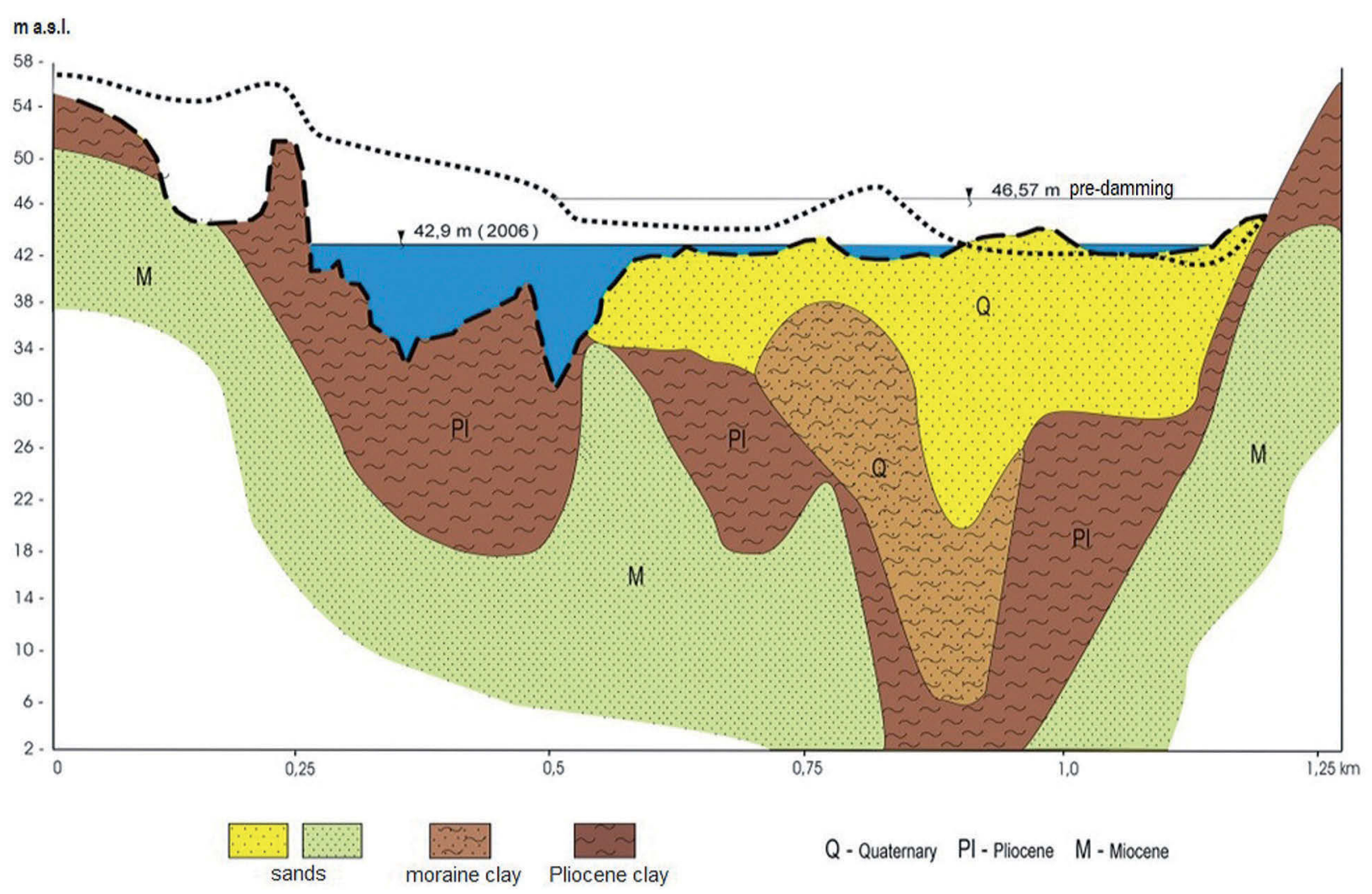

Fig. 4. The geological cross-section of the Vistula valley at the Włocławek dam according to Fąferek (1960 - simplified) with the present channel bed profile

at the right bank of the Vistula below the road bridge in Włocławek and at Łęg Witoszyn. Moreover, the layer of clay may have undergone a complete degradation, in which case the moraine pavement formed in the process rests directly on top of the Pliocene clay formation or a layer of silt (Fig. 3A and 2B - river km 690+00). The thickness of the moraine clay deposits at the study section of the Vistula valley ranges from trace amount of bed paving to over $15 \mathrm{~m}$ at Włocławek (Fig. 3A) and over $20 \mathrm{~m}$ in Torun (Fig. 3B).

The Pliocene clay deposits and the overlying moraine clay constitute (apart from the Ciechocinek Lowland and the section below Silno) a compact mantle of deposits that are resilient to the contemporary Vistula bed erosion processes (Fig. 3A and 3B). Additionally, a layer of silt with thickness of up to $5 \mathrm{~m}$ can be occasionally found at the shallower parts of clay and loam, which is also resilient to the process. It should be noted that the silt deposits can also be found within other sections of the Vistula valley floor. However, since their thickness is relatively small and they do not represent continuous facies, they were omitted in figure 3 (i.a. at the lowering of the sandy-gravel deposits between Silno and Toruń). They are likely to constitute residua of marginal lakes (also as flood facies), which functioned during and after the maximum incision of the ancient Vistula channel. Thus, it can be assumed that silt and other similar deposits do not, aside from the areas marked in figures $3 \mathrm{~A}$ and $3 \mathrm{~B}$, play any significant role in the process nor will they limit the spread of bed erosion below the Włocławek reservoir. Moraine clay found outside the Vistula channel zone but within the range of the valley may display thickness of over $35 \mathrm{~m}$, as is the case of the Szpetal Górny district in Włocławek.

On top of the upper-most layer of the denivelated silty-loamy-clayey deposits one can find a layer of sand and gravel, thickness of which ranges from 0 to $25 \mathrm{~m}$ (Fig. 3A, 2B and 3). They are generally classified as river alluvia, i.e. deposits that take part in the contemporary fluvial processes of the Vistula. The deposits that are subject to transformations in the near-surface layer of the channel bed constitute alluvia (Fig. 3A). However, as shown in the research by Babiński (1992), the maximum channel depth indicated with an echogram in the river pools located at the heads of 


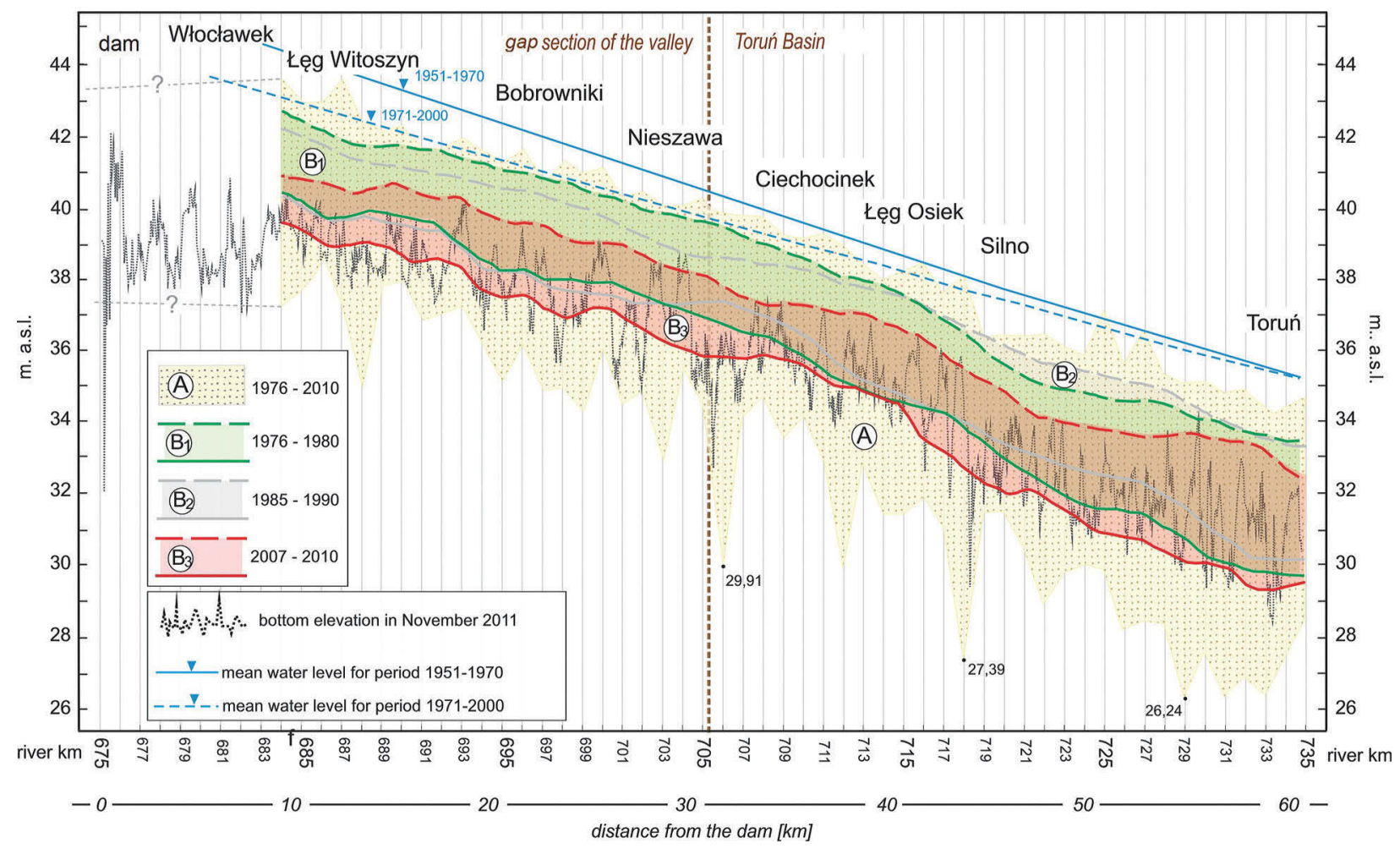

Fig. 5. Thickness diversity of alluvia (A) and the dynamics of sediment transformations (B) caused by the waters of the Vistula at the Włocławek-Torun reach. Moving average of bottom elevation, measured in various periods at intervals of one kilometre of the river course at the deepest (continuous line) and shallowest point (dashed line)

groynes was $12 \mathrm{~m}$, measured from the mean water stages on the Vistula recorded for a succession of many years. Thus, it can be assumed that the 12 metre-thick layer of sandy-gravel deposit also constitutes the alluvia of the contemporary Lower Vistula. Should we accept that the Vistula in the period of Holocene incised to a depth of 3 metres in comparison to the contemporary channel (Tomczak 1982, 1987, Niewiarowski 1987), then the alluvial layer can be assumed to have a thickness of $15 \mathrm{~m}$. Thus, river alluvia do not occur only in the deeper parts of the upper-most layer of clay and loam where fluvioglacial deposits can be found (Fig. 3A). It should be added that such a sedimentological character of the Lower Vistula, i.e. its dichotomous pattern, is evident from the presence of a discontinuous layer of glaciolacustrine silts found in the deeper parts of the denivelated upper-most loamyClayey deposit. This, however, requires further sedimentological research.

The detailed analysis of channel morphology changes along the longitudinal profile of the river in the period of over 40 years (i.e. since the formation of the reservoir) shows that the study reach is characterized by large dynamics of sediment transport (Babiński 1982, 1992, Habel, 2014). It is a consequence of the Włocławek dam operation and arises from the necessity to replenish the river load below the face dam, which accumulates in the upper part of the reservoir. Erosion of bed material ceases upon reaching silty-loamy sediments, which are resilient to washing out (Fig. $3 \mathrm{~A}$ and 5). Where such resilient formations do not occur, the process proceeds until the bottom of the channel reaches an appropriate slope (Babiński 2002).

The dynamics of changes in the character of alluvial deposits are presented in Figure 5. It includes the results of morphometric measurements of the channel conducted in three consecutive seasons: 1976-1980, 1985-1990, 2007-2010 (Fig. $5 \mathrm{~B}_{1}$ and $5 \mathrm{~B}_{3}$ ). Each period is presented in the form of a strip chart featuring a specific width, at which sediments were transformed. The minimum depths where transformations occurred is marked as a dotted line and constitutes the upper-most layer of the deposits, while the minimum is depicted as a dashed line and shows the lower-most part. Measurements were taken in the thalweg of the river. The above mentioned 
data were plotted against the general thickness of alluvia found at the Vistula study reach (Fig. $5 \mathrm{~A})$. It is interpreted as a zone between the extreme minimum and maximum bottom elevations, measured at a given kilometre of the river in the years 1976-2010.

According to Habel (2014), the thickness of the contemporary alluvia in the longitudinal profile of the Vistula study reach vary greatly, ranging from 4.8 to $10.7 \mathrm{~m}$ in the gap section of the river between Włocławek and Ciechocinek, and from 6.0 to $9.8 \mathrm{~m}$ in the Torun Basin (Ciechocinek-Toruń) (Fig. 5A). The average thickness of alluvia at the Torun Basin is higher by $1.5 \mathrm{~m}$ in comparison to the gap section.

The longitudinal profile of the study reach for the period of last 40 years displays a tendency of the river to transform deeper alluvia both at the gap section of the valley and within the Torun Basin (Fig. 5 - compare $\mathrm{B}_{1}$ and $\mathrm{B}_{3}$ ). Such an occurrence indicates that the channel bellow the Włocławek dam is progressively shifting its pattern and is becoming straightened (Babiński 1992). At the same time, sediments are being transformed within layers of decreasing thickness - difference between the minimum and maximum values in a given period (Fig. 5 e.g. $\left.B_{3}\right)$. This situation may arise from the loss of alluvial sediments participating in fluvial transport. In the years 1976-1980, at the reach between Włocławek and Ciechocinek (gap section of the valley), sediments were transformed in the layer of thickness ranging from 2.4 to $2.7 \mathrm{~m}$ (Fig. 5 $\mathrm{B}_{1}$ ), and in the range of 1.7 to $2.3 \mathrm{~m}$ in in the years 2007-2010 (Fig. 5B ${ }_{3}$ ). Thus, within 30 years, the capacity of the river to vertically transform alluvia decreased by $22 \%$. On the other hand, at the reach between Ciechocinek and Torun (Torun Basin), as far as the first period is concerned, the layer where alluvia were being altered displayed thickness ranging from 2.5 to $3.9 \mathrm{~m}$, and in the recent years - from 2.2 to $4.1 \mathrm{~m}$, with general tendency to narrow the range of sediment transformation by $5 \%$. The thickness up to which alluvia were being processed in Torun increased slightly in the years 2007-2010 in comparison to the previous period (Fig. 5B $\mathrm{B}_{3}$ ).

The above analysis appears to support the claim that the Vistula channel at its gap section (Włocławek-Ciechocinek) reached the erosion floor of the Vistula valley in many places. In other words, the alluvial cover once formed by the river waters was eliminated.

\section{Bed erosion with regard to the geological structure - conclusions}

From the analysis of geological conditions of the lower Vistula valley floor in the zone stretching between the banks and the river embankments at the reach from Włocławek to Torun we may conclude what follows:

1. The oldest deposits that can be in direct contact with erosion-resilient formations, which belong to sandy-gravel facies of fluvioglacial and alluvial origins include the Mesozoic deposits of marly limestone from the Jurassic and Cretaceous periods, which can be found in the proximity of the Ciechocinek Lowland (exclusively). The upper-most layer of the Cretaceous deposits lies at the minimum elevation of $25 \mathrm{~m}$ a.s.l. At present there are no erosion incisions that would reach this depth. Moreover, there are reasons to assume that within the zone under study the Mesozoic deposits are covered with a thin layer of Pliocene clay.

2. The continuity of the loam layer may be locally disrupted at river kilometre $686+00-$ 688+00 and 723+00 - 727+00, uncovering the Miocene sediments (brown coal and sand) in situ. These sections feature the highest vulnerability to bed erosion.

3. On top of the Miocene (such as pt. 2) and Cretaceous (in Ciechocinek) deposits there is a nearly continuous mantle of erosion-resilient Pliocene clay, with a gap between river kilometre $712+00$ and $726+00$. As a result, erosion below the reservoir is considerably constrained in time and space.

4. On the highly denivelated surface of Pliocene clay (consequence of pressure exerted by the ice sheet - glaciotectonics, diverse bed erosion of ancient Vistula?) there is a layer of moraine clay in the form of islets (erosion?), often covered with glaciolacustrine silts. These three strata representing different facies (loam, clay, silts) constitute a layer that limits bed erosion.

5. Due to the glaciotectonic processes, the Miocene deposits may interact with the glacioflu- 
vial and Holocene alluvia, which are subject to bed erosion. Such an occurrence would trigger the process of river channel incision below the reservoir.

6. The sandy-gravel deposits subjected to bed erosion below the reservoir display thickness ranging from 0 to $20 \mathrm{~m}$. This is due to the fact that their lower-most layer of loam, silt and clay is highly denivelated.

7. The sandy-gravel deposits found up to the depth of $12 \mathrm{~m}$ from the channel bed surface constitute the Holocene alluvia of the Vistula (the maximum depth of river pools is considered the boundary). Deposits found underneath should be regarded as fluvioglacial.

By analysing the course of bed erosion below the Włocławek dam in connection to the geological structure of the valley floor we were able to determine what follows:

1. For over 44 years since the Włocławek reservoir was formed, river alluvia were selectively washed out from the channel bed and transported down the river (partial and temporary deposition of river load in the zone located between the groynes) (Babiński 1982, 1992). Bed erosion extended beyond the study area (Habel 2014).

2. River incision does not proceed evenly in time and space due to a denivelated, erosion-resilient bed surface (silt, clay, boulder clay, moraine till, loam).

3. For most of the part, the channel banks are devoid of alluvia and are mainly composed of silt and Pliocene clay, sometimes moraine clay, erosion of which left a moraine till.

4. Where the upper-most layer of the Pliocene and Pleistocene deposits became shallower (due to the glaciotectonic processes), there are currently sills of stone and loam, which cover the entire width of the channel. These forms largely prevent further bed incision and render river transport impossible. Such sill are currently confirmed at river kilometre $683+00$ (Fig. 2D) and 690+00.

5. The irregular course of channel bed incision (time and space) causes differences in bed and water surface slopes at the erosion reach of the Vistula. These differences are expected to further increase.
Given the course of bed erosion below the Włocławek reservoir as well as the inhomogeneous geological structure of the valley floor in the zone between the edge of water and the embankments, we can make the following assumptions:

1. The alluvial deposits will continue to degrade, leading to their permanent elimination at river kilometre $680+00-683+00$ and $689+00$ - 693+00 (in the entire width of the channel - sills). Alluvia occurring in the remaining section, apart from river kilometre 685+00 $687+00$ and $711+00-712+00$, will feature partial degradation.

2. While slowly proceeding incision of the channel bed into the sills at river kilometre $680+00$ - 683+00 and 689+00 - 693+00 will partially limit in time and space the process of bed erosion, it will not be eliminated.

3. Regardless of the extent to which bed erosion is inhibited, it will continue to threaten the entire hydrotechnical infrastructure and may eventually lead to an ecological catastrophe.

\section{Acknowledgments}

The study was conducted as part of the project of the Polish Ministry of Science and Higher Education in the years 2010-2012 under no. N N306 437438.

\section{References}

Babiński Z., 1982. Procesy korytowe Wisły poniżej zapory wodnej we Włocławku (Fluvial processes of the Vistula River below the Włocławek dam). Dokumentacja Geograficzna 1-2.

Babiński Z., 1992. Współczesne procesy korytowe dolnej Wisły (The presentDay fluvial processes of the Lower Vistula River), Prace Geograficzne 157.

Babiński Z., 2002. Wpływ zapór na procesy korytowe rzek aluwialnych (Impact of the dams on the fluvial processes on alluvial rivers). Akademia Bydgoska im. Kazimierza Wielkiego.

Babiński Z., Habel M., 2009. Dynamika strefy akumulacyjnej poniżej czoła strefy erozyjnej Zbiornika Włocławskiego (Dynamics of the accumulation zone below erosion zone of the Włocławek Reservoir). In: A.T. Jankowski, D. Absalon, R. Machowski, M. Ruman (eds), Przeobrażenia stosunków wodnych w warunkach zmieniającego się środowis$k a$, WNoZ UŚ Sosnowiec.

Banach M., 1986. Przekształcenia brzegów zbiornika włocławskiego (Deformation of the Włocławek's Reservoir banks). In: Szupryczynski J. (ed.), Zbiornik 
Włocławski - niektóre problemy z geografii fizycznej, Dokumentacja Geograficz, 5: 25-37.

Beylich A., Lamoureux S.F., Decaulne A., 2011., Developing frameworks for studies on sedimentary fluxes and budgets in changing cold environments. Quaestiones Geographicae 30(1): 5-18. DOI 10.2478/v10117-011-0001-5.

Alekseevsky N. I. and Chalov S. R., 2009. Hydrological impacts of braided channels. Moscow State University, Russia.

Falkowski E., 1967. Ewolucja holoceńskiej Wisły na odcinku Zawichost - Solec i inżyniersko-geologiczna prognoza jej dalszego rozwoju (Evolution of the Vistula River in Holocene in the reach between Zawichost and Solec). Biul. Instytutu Geologicznego 198 (IV): 57-131.

Falkowski E., 1982. Wisła w geografii Polski - przyroda rzeki (Vistula on the Polish Geography). In: Piskozub A. (ed.), Wista. Monografia rzeki. Wyd. Komunikacji i Łączności.

Falkowski E., Kowalski W.C., 1987. Buried river valleys and buried alluvia and their engineering geological significance. Bulletin of the International Association of Engineering Geology (1987) 35: 47-56.

Falkowski T., 2010. Basement of the alluvia influence on the channel pattern in example of selected reach of the Pilica River. Annals of Warsaw University of Life Sciences SGGW. Land Reclamation 42(1): 93-104.

Fąferek B., 1960. Inżynierskie badania geologiczne dla stopnia wodnego we Włocławku (Engineering geological surveys of the Włocławek water barrege). Przeglad Geologiczny 2.

Galon R., 1934. Dolina dolnej Wisły, jej kształt i rozwój na tle budowy dolnego Powiśla. Badania Geograficzne nad Polskg Pótnocno-Zachodnia 12-13.

Habel M., 2007. Fluvial processes below the Wloclawek dam. Proceedings of the $10^{\text {th }}$ International Symposium on River Sedimentation. August 1-4, Moscow, Russia, vol. 2.

Habel M., 2014. Dynamics of the Vistula River channel deformations downstream of Wtoctawek Reservoir. Kazimierz Wielki University in Bydgoszcz (in print).
Migoń P., 2006. Geomorfologia (Geomorphology). PWN, Warszawa s.

Niewiarowski W., 1987. Evolution of the Lower Vistula valley in the Unisław Basin and at the river gap to the north of Bydgoszcz-Fordon. In: Starkel L. (ed.), Evolution of the Vistula River valley during the last 15000 years, Part II, Geogr. Studies, Spec. Iss., 4.

Pożaryski W., 1965. Budowa geologiczna doliny Wisły środkowej między Sandomierzem i Puławami (Geological structure of the Middle Vistula valley between Sandomierz and Puławy). Geologiczne problemy zagospodarowania Wisty środkowej, Katowice.

Tomczak A., 1982. The evolution of the Vistula River valley between Torun and Solec Kujawski during the Late Glacial and the Holocene. In: Starkel L. (ed.), Evolution of the Vistula River valley during the last 15.000 years, Part I, Geogr. Studies, Spec. Iss., 1: 109-130.

Tomczak A., 1987. Evolution oft he Vistula Valley in the Torun Basin in the late glacial and holocene. In: Starkel L. (ed.), Evolution of the Vistula River valley during the last 15000 years, Part II, Geogr. Studies, Spec. Iss., 4.

Twindale C.R., 2004. River pattern and their meaning. Earth-Science Reviews 67: 159-218.

Wiśniewski E., 1976. Rozwój geomorfologiczny doliny Wisły pomiędzy Kotliną Płocką a Kotliną Toruńską (Geomorphological development of the Vistula valley between Plock Basin and Toruń Besin). Prace Geograficzne IG PAN 119.

Wiśniewski E., 1987. The evolution of the Vistula river valley between Warsaw and Płock Basins during the last 15.000 years. In: Starkel L. (ed.), Evolution of the Vistula River valley during the last 15.000 years, Part II, Geogr. Studies, Spec. Iss., 4. 